\title{
7 - Transverse rectus abdominis musculocutaneous flap (TRAM flap) - experimental model in rats $^{1}$
}

\author{
Pedro Bins Ely ${ }^{2}$ \\ Lydia Masako Ferreira ${ }^{3}$
}

\begin{abstract}
Ely PB. Transverse rectus abdominis musculocutaneous flap (TRAM flap) - experimental model in rats. Acta Cir Bras [serial online] 2003 Vol 18 Special Edition. Available on URL: http://www.scielo.br/acb.

ABSTRACT - The objective of this paper was to report the use of an experimental model of the Transverse Rectus Abdominis Musculocutaneous flap (TRAM flap), in rats. Thirty male Wistar rats weighing 180 to $220 \mathrm{~g}$ were submitted to the TRAM flap procedure. This article reports on the use of the caudally based, right unipedicled TRAM flap.
\end{abstract}

KEY WORDS - Surgical flaps. Rectus abdominis. Rats. Surgery.

\section{Introduction}

Post-mastectomy breast reconstruction have been the object of a series of studies by plastic surgeons and mastologists. Among the several technichs proposed, the Transverse rectus abdominis musculocutaneous flap (TRAM flap) have been the preferred choice in many services that work in the area of reconstructive surgery. ${ }^{1,2}$

Aiming to otimize the use of the flap, several authors tryed do study the variants of its utilization, including: the use of one or both rectus abdominis as pedicle; the effect of drugs in the perfusion and viability of the flap; the use of the delay procedure and the effect of different periods of time between the delay procedure and the TRAM flap procedure.

To study these variants, animal models were developed, including pigs ${ }^{3}$, mouses ${ }^{4}$ and rats ${ }^{5,6,7,8,9}$. These animal models set the stage for further studies about the transverse rectus abdominis muscle flap. ${ }^{10,11,12}$

\section{Proposition}

The proposition of this study is to report and spread the use of the experimental model of the transverse rectus abominis muscle flap (TRAM flap) in rats. The rat TRAM flap can be designed with the use of one or both rectus abdominis as a pedicle. The present article describes the unilatereal monopedicled rectus abdominis flap, caudally based on the right muscle.

1. Federal University of São Paulo - Paulista School of Medicine.

2. Post-graduation student Plastic Surgery Division of Surgery Department - Federal University of São Paulo - Paulista School of Medicine - UNIFESP-EPM. Brazil.

3. Head of Plastic Surgery Division of Surgery Department and Coordinator of Post-graduation Program in Reconstructive Plastic Surgery - UNIFESP - EPM. Brazil. 


\section{Method description}

The expenimental animal of this model is the Wistar rat (Rattus norvegicus albinus, Rodentia, Mammalia), male, adult, weighting 180 -220 g.

In the pre-operatory pediod, the animals were selected, kept in individual cages, weighted and left without any alimentary restriction until the time of the study.

The animals were anesthesized by intra muscular administration of $10 \mathrm{mg} / \mathrm{kg}$ of ketamin associated with $0,1 \mathrm{mg} / \mathrm{kg}$ of tiazin.

Before the operation, the animals were positioned in dorsal decubit, imobilyzed in a surgical table and submitted to depilation by manual traction. Antissepsy was made with iodine and the operating field was demencated by sterylized dresses.

The transverse rectus abdominis musculocutaneous flap procedure:

The flap was designed, having $5 \mathrm{~cm}$ latero-laterally and $3 \mathrm{~cm}$ craneo-caudally, positioned $1 \mathrm{~cm}$ caudally to the xifoid apendix (Figure 1).
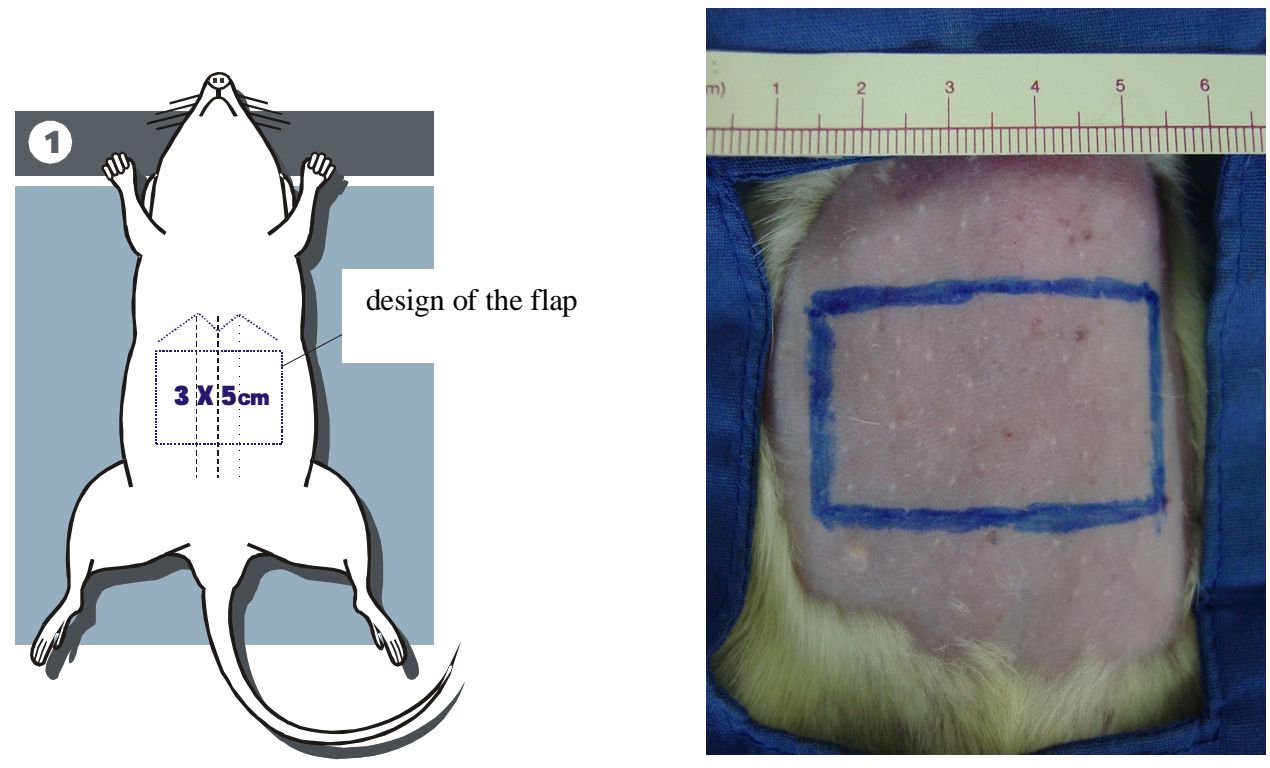

FIGURE 1 - Drawing and photography showing the design of the transverse rectus abdominis musculocutaneous flap.

The skin was cut in all the perimeter of the flap (Figure 2). 

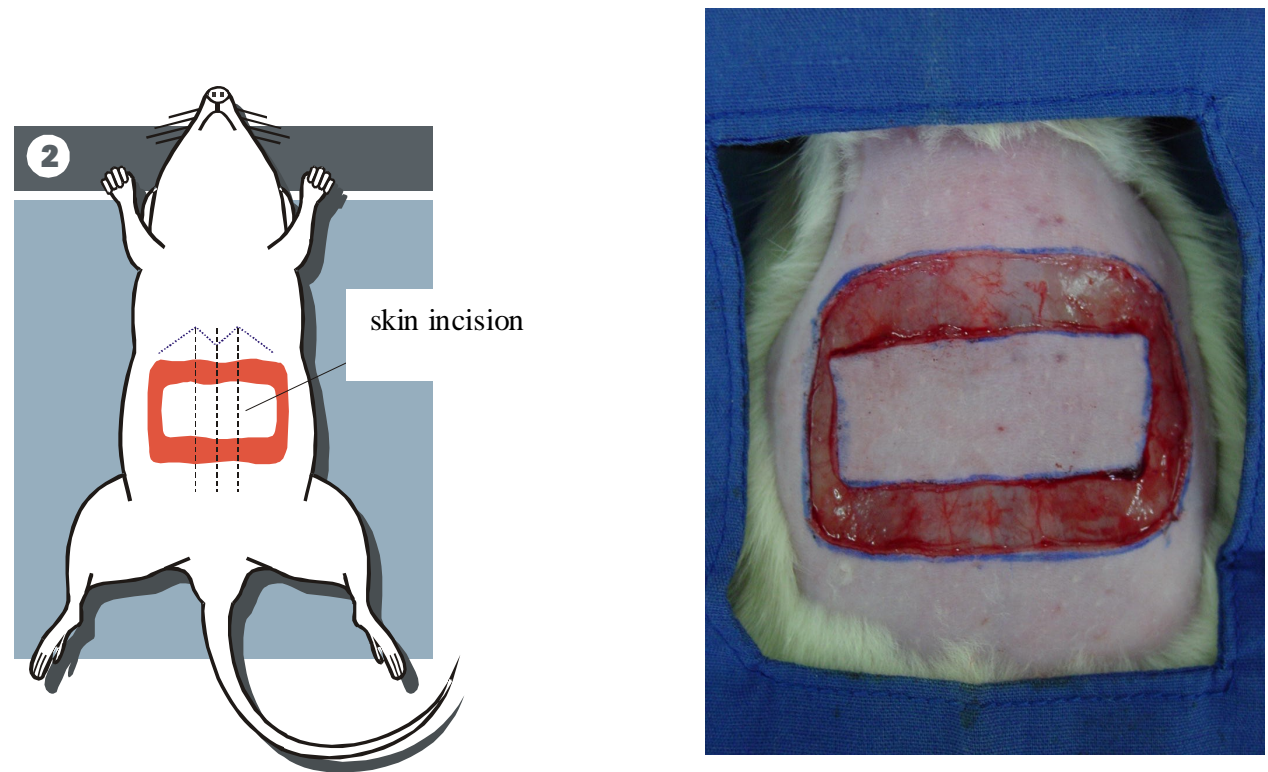

FIGURE 2 - Drawing and photography showing the aspect of the flap after skin incision.

The dissection of the flap began on the contralateral side (left) of the pedicle, with the dissection on the supra-aponeuroric plane from lateral to medial, until reaching the midline - linea alba (Figure 3).
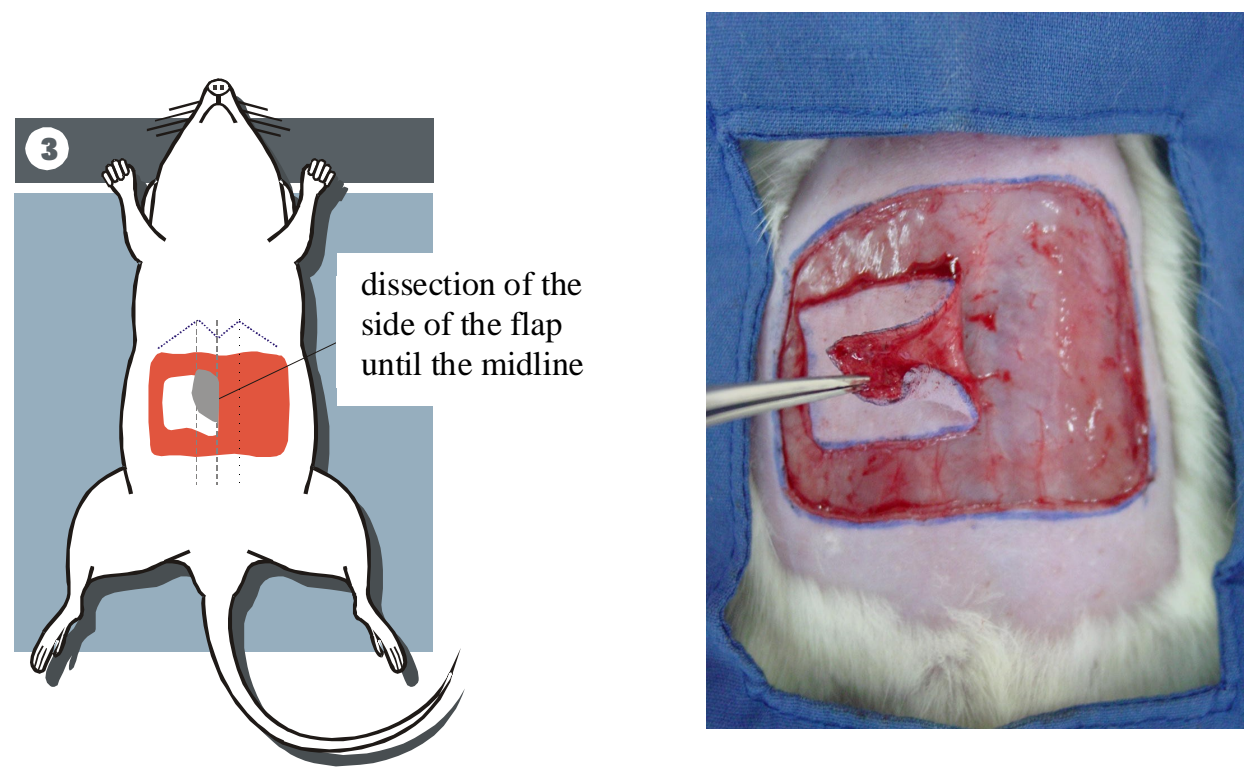

FIGURE 3 - Drawing and photography that shows the dissection of the flap on the contralateral side (left) of the pedicle, uintil the midline (linea alba).

On the ipsilateral side (right) of the pedicle, the flap was dissected until the lateral border of the right musculus rectus abdominis was reached (Figure 4). 

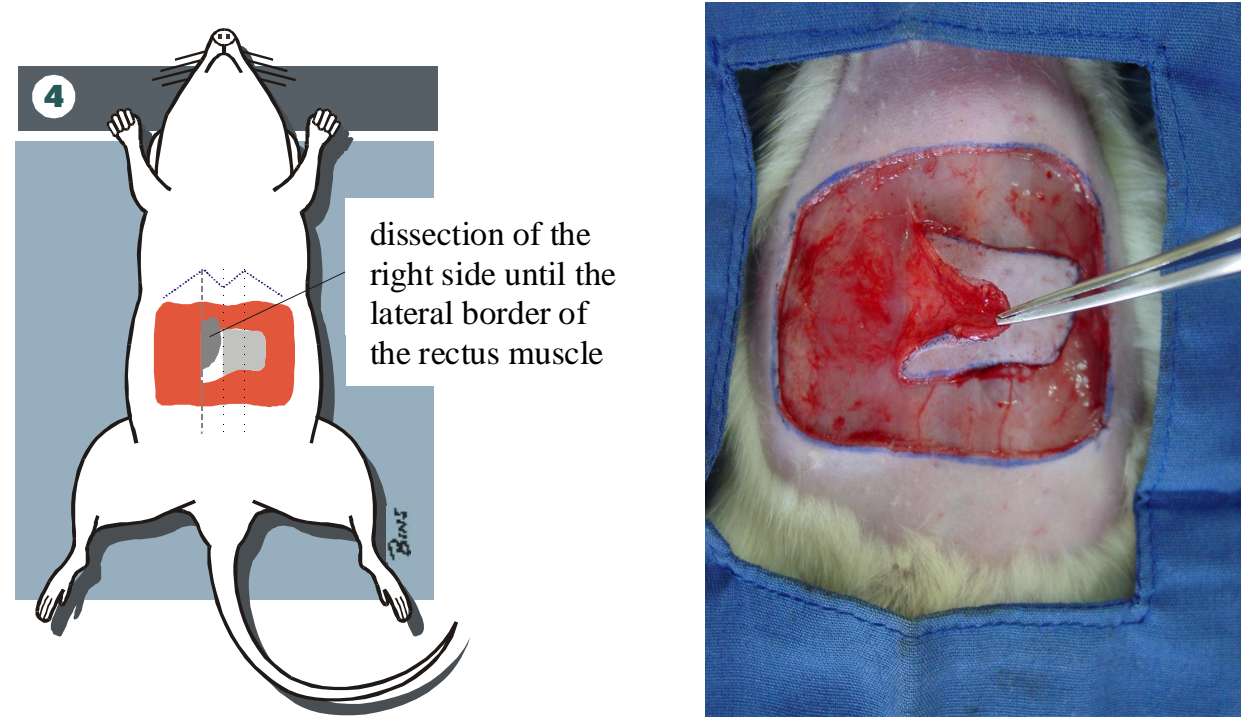

FIGURE 4 - Drawing and photography that shows the dissection of the flap on the ipsilateral side (right) of the pedicle, until the lateral border of the right rectus muscle was reached.

The flap was then elevated by incision along the midline (linea alba) (Figure 5).
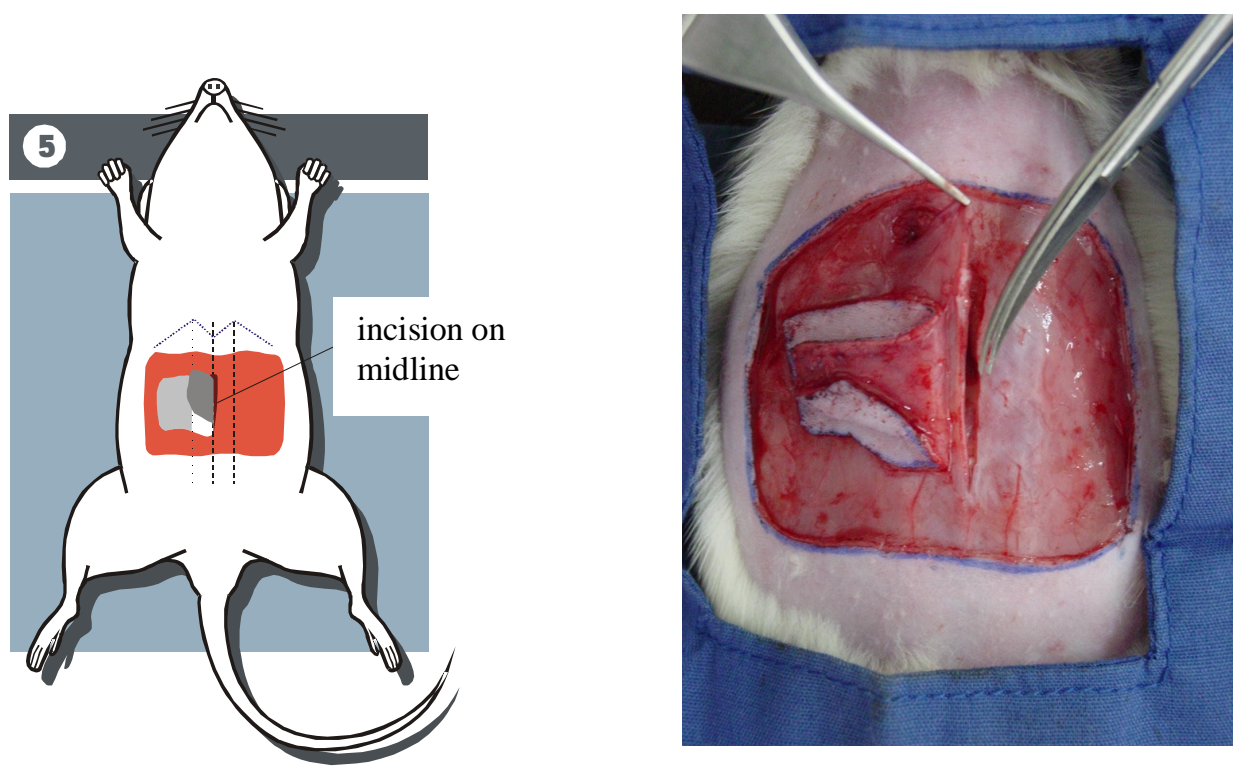

FIGURE 5 - Drawing and photography that shows the incision along the linea alba to elevate the flap. 
The elevation of the flap is completed by incision of the cranial portion, and the lateral border of the rectus abdominis muscle (Figure 6), so the flap stays pedicled only by the right rectus abdominis muscle, based on the right caudal epigastric artery (Figures 7 and 8 ).
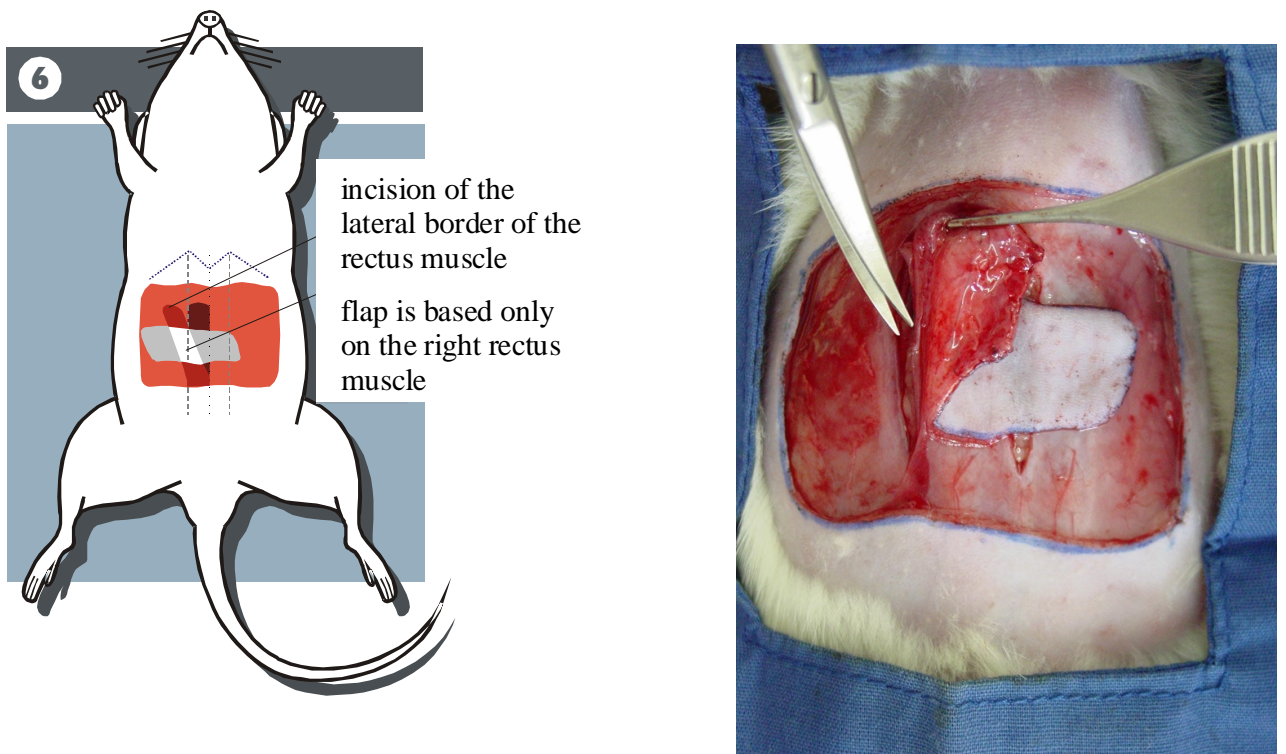

FIGURE 6 - Drawing and photography that shows the incision of the lateral border of the right rectus abdominis muscle, for elevation of the flap.
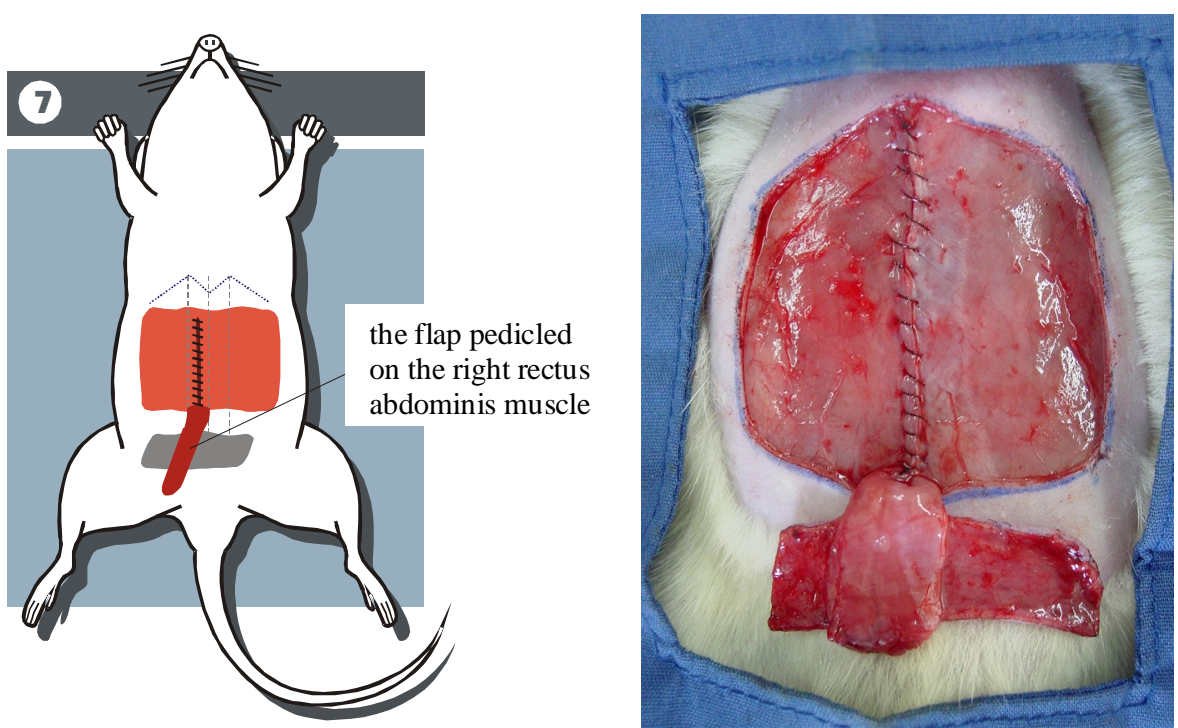

FIGURE 7 - Drawing and photography showing the closure of the area from which the muscle was taken off. The flap stays pedicled only on the right rectus abdominis muscle. 

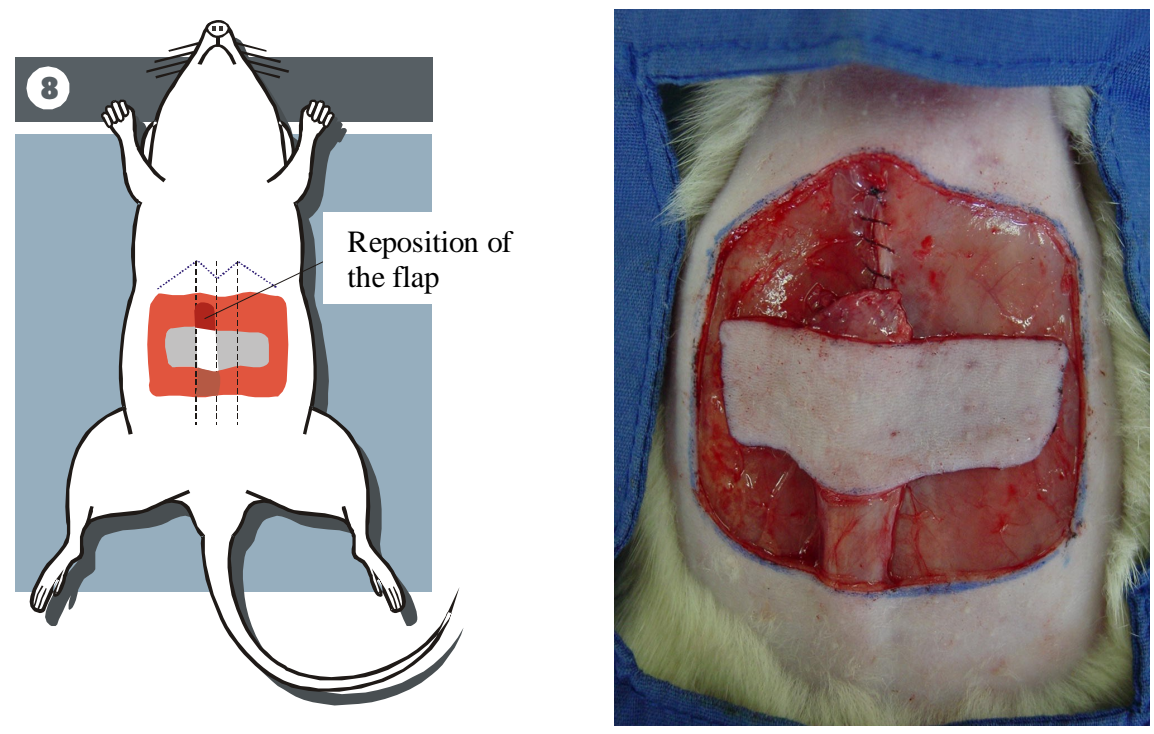

FIGURE 8 - Drawing and photography that shows the reposition of the flap.
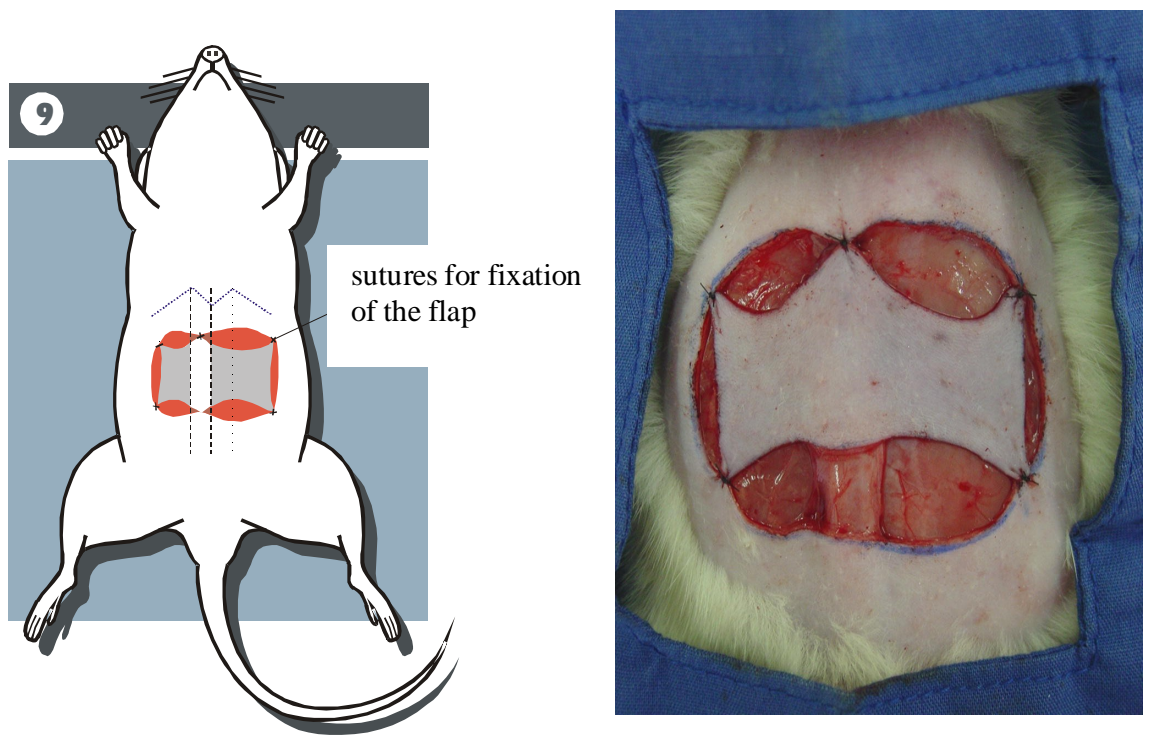

FIGURE 9 - Drawing and photography that shows the sutures for fixation of the flap.

Then, the area from which the muscle was taken off is closed with a running suture of 5-0 nylon. The skin is then sutured with 5-0 nylon, first with separate sutures for fixation of the flap, on the midline, and on the four edges of the flap (Figure 9).

The closure of the skin was made by a running suture, throughout the perimeter of the flap (Figure 10). 

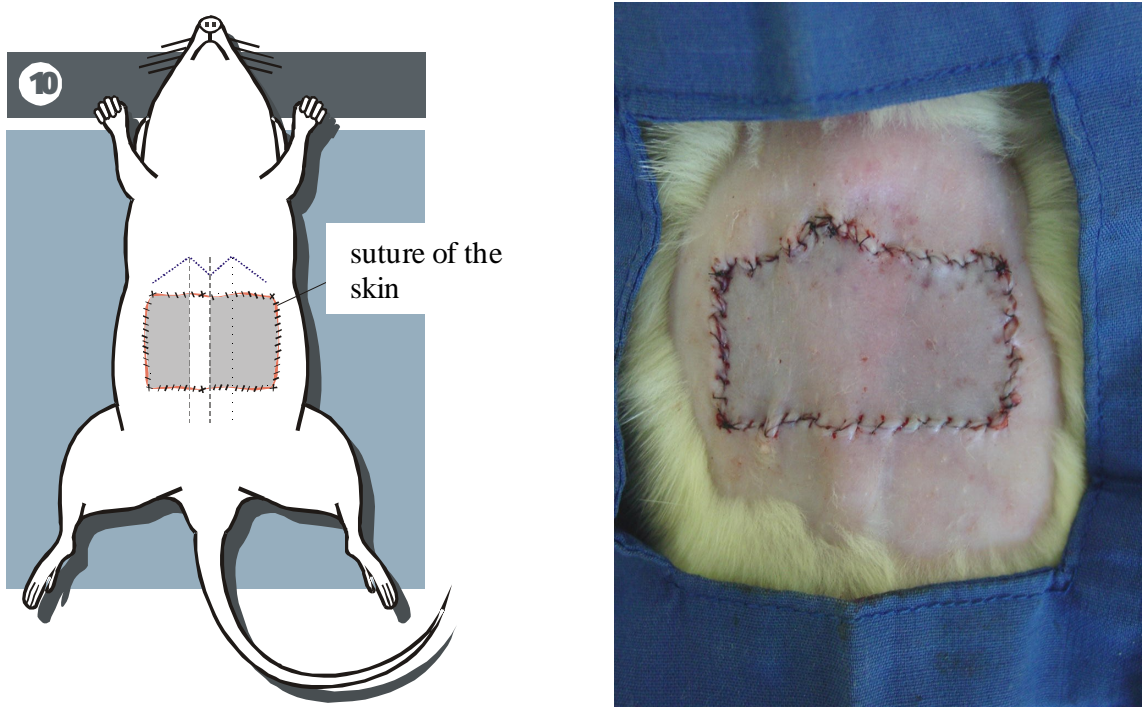

FIGURE 10 - Drawing and photography that shows the suture of the skin, and the aspect of the flap at the end of the procedure of the rat TRAM flap.

\section{Perspectives}

The experimental model of the transverse rectus abdominis musculocutaneous flap (TRAM flap) is feasible and is effective as an experimental model in rats. The perspective of the use of this experimental model in the study of variants of utilization of the flap is wide, as well as the study of the effect of drugs and their influence on the perfusion and viability of the flap.

\section{References}

1. Hartrampf CR, Scheflan M, Black PW. Breast reconstruction with a transverse abdominal island flap. Plast Recontr Surg 1982;69:216-24.

2. Ely JF, Barcellos JS, Ely PB, Souza EP. Reconstrução do relevo mamário pós-mastectomia. Rev Med St Casa 1996;7(14):1460-7.

3. Dorion D, Boyd JB, Pang CY. Augmentation of transmidline skin perfusion and viability in transverse rectus abdominis myocutaneous (TRAM) flaps in the pig. Plast Reconstr Surg 1991; 88:642-9.

4. Losken A, Swartz MA, Van Den Abbeele AD, Jain RK, Slavin SA. A Potential Murine Model for Flap Related Investigations. Plast Reconstr Surg 2001;107:1504-8.

5. Dunn RM, Mancoll J. Flap models in the rat: A review and reappraisal. Plast Reconstr Surg 1992; 90:319-28. 6. Dunn RM, Huff W, Mancoll J. The rat rectus abdominis myocutaneous flap: A true myocutaneous flap model. Ann Plast Surg 1993;31:352-7.

7. Özgentas HE, Shenaq S, Spira M. Development of a TRAM flap model in the rat and study of vascular dominance. Plast Reconstr Surg 1994;94:1012-7.

8. Hallock GG, Rice DC. Physiologic superionity of the anatomic dominant pedicle of the TRAM flap in a rat model. Plast Reconstr Surg 1995; 96:111-8. 
9. Ely PB, Miltersteiner AR, Hoff FC. Retalho miocutâneo transverso de músculo reto abdominal (TRAM flap) - modelo experimental em ratos. Acta Cir Bras 1997;12 (Suppl. 2):75.

10. Clugston PA, Perry LC, Fisher J, Maxwell GP. A rat transverse rectus abdominis musculocutaneous flap model: Effects of pharmacological manipulation. Ann Plast Surg 1995;34:154-61.

11. Restifo RJ, Ahmed SS, Isenberg JS, Thomson JG. Timing, magnitude, and utility of surgical delay in the TRAM flap: I. Animal studies. Plast Reconstr Surg 1997;99:1211-6.

12. Ely PB, Goldenberg S, d'Acampora AJ. Efeito da autonomização no retalho miocutâneo abdominal transverso de músculo reto abdominal - estudo experimental em ratos. Acta Cir Bras 1999;14 (supl.2):25.

Ely PB, Ferreira LM. Modelo experimental do retalho musculocutâneo abdominal transverso de músculo reto do abdome (TRAM flap) em ratos. Acta Cir Bras [serial online] 2003 Vol 18 Edição Especial. Disponível em URL: http://www.scielo.br/acb.

RESUMO - Este artigo relata e divulga um modelo experimental do retalho musculocutâneo abdominal transverso de músculo reto do abdome (TRAM flap), em ratos. Foram utilizados 30 ratos Wistar (Rattus norvegicus albinus, Rodentia, Mammalia) machos, adultos, com peso individual variando entre 180 e 220 gramas. Os animais foram submetidos ao procedimento operatóno do retalho musculocutâneo abdominal transverso de músculo reto do abdome (TRAM flap), de base caudal com pedículo do músculo reto do abdome unilateral à direita.

DESCRITORES - Retalhos cinúrgicos. Reto do abdome. Ratos. Cinurgia.

Comespondence:

Conflict of interest: none Finantial source: none

Pedro Bins Ely

UNIFESP-EPM, Plastic Surgery Division, Surgery Division

Rua Napoleão de Barros, $715,4^{\circ}$ andar

04024-900 São Paulo - SP

Tel: (11)557604118 FAX: (11) 55716579

sandra.dcir@epm.br_pedrobinsely@terra.com.br

Data do recebimento: 22/ 04/2003

Data da revisão: $18 / 05 / 2003$

Data da aprovação: $28 / 07 / 2003$ 